\title{
PERILAKU IBU DALAM IMUNISASI DASAR LENGKAP DI PUSKESMAS GAYAM KABUPATEN SUMENEP
}

\author{
MOTHER'S BEHAVIOR IN COMPLETE BASIC IMMUNIZATION AT \\ GAYAM COMMUNITY HEALTH CENTER SUMENEP REGENCY
}

\author{
Miftahol Hudhah ${ }^{1)}$, Atik Choirul Hidajah ${ }^{2)}$ \\ ${ }^{1,2}$ Departemen Epidemiolgi, \\ Fakultas Kesehatan Masyarakat, Universitas Airlangga, Surabaya.
}

\begin{abstract}
Immunization is an effort to boost the immunity of someone actively against a disease, so when exposed to the disease will not get sick or only experience a mild ache. The main goal of immunization is to lower of pain, disability and death due to diseases that can be prevented by Immunization (PD3I). To achieve these objectives it must achieve coverage of the basic immunization of 91\%. The achievement of basic immunization at the Gayam health center does not meet the target. One of the causes is not achieving the target because of the mother foctor in immunizated his son. This study was conducted to describe and analyze the relationship factors of mother in the achievement of basic immunization in region work of Gayam health center Sumenep regency. This study use cross sectional design. The subject were taken from a population by simple random sampling technique. The independent variables in this study were the age of mother, mother's level of education, occupation of mother, mother's level of knowledge, maternal attitudes and beliefs of mother. The results showed that the variables that associated in the achievement of basic immunization are mother's level of education $(p=0,020)$, mother's knowledge level $(p=0,000)$, beliefs of mother $(p=$ $0.000)$ and the maternal attitudes $(p=0.000)$. While the variable age of mother and occupation of mother not associated in the achievement of basic immunization because the $p$ value > 0.05. Conclusion of this study is factors of associated in the achievement of basic immunization are mother's level of education, mother's knowledge level, beliefs of mother and maternal attitudes. Therefore it is necessary for the addition of knowledge's mother through the delivery of information, in addition health workers provides an explanation to the mother related to the incidence of post followup immunization so that mothers believe that immunizations have an impact well and the mother was able to behave better towards immunization.
\end{abstract}

Keyword: basic immunization, beliefs of mother, maternal attitudes, mother's knowledge level, mother's level of education

Abstrak: Imunisasi adalah suatu upaya untuk meningkatkan kekebalan seseorang secara aktif terhadap suatu penyakit, sehingga bila suatu saat terpapar dengan penyakit tersebut tidak akan sakit atau hanya mengalami sakit ringan. Tujuan utama imunisasi untuk menurunkan angka kesakitan, kecacatan dan kematian akibat Penyakit yang Dapat Dicegah Dengan Imunisasi (PD3I). Untuk mencapai tujuan tersebut maka harus mencapai cakupan imunisasi dasar lengkap sebesar 91\%. Pencapaian imunisasi dasar lengkap di Puskesmas Gayam belum memenuhi target. Salah satu penyebab belum tercapaianya target tersebut yaitu karena faktor ibu dalam mengimunisasikan anaknya. Penelitian ini dilakukan untuk mendeskripsikan dan menganalisis hubungan faktor ibu dalam pencapaian imunisasi dasar lengkap di wilayah kerja Puskesmas Gayam Kabupaten Sumenep. Penelitian dilakukan dengan rancang bangun cross sectional. Subyek penelitian diambil dari populasi dengan cara simple random sampling. Variabel bebas pada penelitian ini adalah usia ibu, tingkat pendidikan ibu, 
pekerjaan ibu, tingkat pengetahuan ibu, kepercayaan ibu dan sikap ibu. Hasil penelitian menunjukan bahwa variabel yang berhubungan dalam pencapaian imunisasi dasar lengkap yaitu tingkat pendidikan ibu $(\mathrm{p}=0,020)$, tingkat pengetahuan ibu $(\mathrm{p}=0,000)$, kepercayaan ibu $(\mathrm{p}=0,000)$ dan sikap ibu $(\mathrm{p}=0,000)$. Sedangkan variabel usia ibu dan pekerjaan ibu tidak berhubungan dalam pencapaian imunisasi dasar lengkap karena nilai $p>0,05$. Kesimpulan dari penelitian ini adalah faktor yang berhubungan dalam pencapaian imunisasi dasar lengkap yaitu tingkat pendidikan ibu, tingkat pengetahuan ibu, kepercayaan ibu dan sikap ibu. Oleh karena itu perlu dilakukan penambahan pengetahuan ibu memalui penyampaian informasi, selain itu petugas kesehatan memberikan penjelasan kepada ibu terkait kejadian pasca ikutan imunisasi sehingga ibu percaya bahwa imunisasi berdampak baik dan ibu mampu bersikap baik terhadap imunisasi.

Kata Kunci: imunisasi dasar, kepercayaan ibu, sikap ibu, tingkat pendidikan ibu, tingkat pengetahuan ibu

\section{PENDAHULUAN}

World Health Organization (WHO) melaporkan bahwa terjadi penurunan angka kematian balita (AKB) pada tahun 19902013. Pada tahun 1990 kematian balita sebesar 12,6 juta anak, sedangkan pada tahun 2013 kematian balita sebesar 6,3 juta anak (WHO, 2014). Menurut Kemenkes RI (2014) angka kematian balita pada tahun 2015 masih jauh dari target AKB yaitu sebesar 23 per 1000 kelahiran hidup. AKB secara global di dunia masih tinggi yaitu sebesar 46 per 1000 kelahiran hidup (WHO, 2014).

Salah satu cara untuk mengurangi angka kematian pada bayi ataupun anak yaitu memalui pemberian imunisasi. WHO menyebutkan bahwa terdapat 1,5 juta anakmeninggal akibat Penyakit yang Dapat Dicegah Dengan Imunisasi (PD3I) di tahun 2013. Namun pada tahun 2015 lebih dari 1,4 juta anak di dunia meninggal karena PD3I (Kemenkes RI, 2015). Meskipun terjadi penurunan kematian dari tahun sebelumnya, perlu adanya upaya preventif untuk mengatasi PD3I.

Prevalensi kasus PD3I akan menunjukkan peningkatan maupun penurunan tergantung jenis penyakitnya (Depkes RI, 2005). Berdasarkan Riskesdas tahun 2007, prevalensi penyakit campak secara nasional sebesar 1,8\% (Depkes RI, 2007). Hasil Riskesdas tahun 2007 juga menyebutkan bahwa prevalensi Hepatitis B sebesar 9,4\%, prevalensi penyakit Tuberkulosis sebesar 0,4\% (Kemenkes RI, 2014).

Imunisasi seharusnya dapat menurunkan angka kematian anak akibat
PD3I melalui peningkatan capaian imunisasi dasar lengkap disetiap daerah (WHO, 2014). Imunisasi merupakan cara untuk meningkatkan kekebalan seseorang pada suatu penyakit, sehingga apabila terkena penyakit tersebut tidak akan sakit atau hanya mengalami sakit ringan. Apabila anak tidak mendapat imunisasi lengkap maka akan berdampak pada PD3I dan memberikan risiko AKB. Beberapa penyakit menular PD3I yang menyerang anak berumur 0-11 bulan adalah Tuberkulosis (TBC), Difteri, Tetanus, Hepatitis B, Pertusis, Campak, dan Polio. Anak yang mendapatkan imunisasi akan terlindungi dari PD3I tersebut, sehingga akan terhindar dari kecacatan atau kematian (Kemenkes RI, 2016).

Imunisasi dasar yaitu imunisasi rutin yang diberikan pada bayi sebelum berusia satu tahun. Kegiatan imunisasi dasar dilaksanakan secara terus-menerus sesuai jadwal (Kemenkes RI, 2013). Permenkes RI No 42 tahun 2013 menyatakan bahwa jenis imunisasi dasar terdiri dari Bacillus Calmette Guerin (BCG), DiphtheriaPertusis Tetanus-Hepatitis $B$ (DPT-HB) atau Diphtheria Pertusis Tetanus-Hepatitis B-Hemophilus Influenza type B (DPT-HB-Hib), Hepatitis B, Polio, dan Campak.

Riskesdas (2013) menyatakan bahwa terdapat peningkatan angka cakupan imunisasi dasar lengkap dari tahun 20072013. Pada tahun 2007 angka cakupan imunisasi dasar lengkap sebesar 41,6\% dan pada tahun 2013 angka cakupan imunisasi dasar lengkap meningkat menjadi 59,2\%. Akan tetapi, pada tahun 2013 terdapat cakupan imunisasi dasar tidak lengkap 
sebesar $32,1 \%$ dan terdapat $8,7 \%$ anak tidak pernah diimunisasi.

Angka cakupan imunisasi dasar lengkap mengalami fluktuasi pada tahun 2013-2015 di wilayah kerja Puskesmas Gayam Kecamatan Gayam Kabupeten Sumenep Provinsi Jawa Timur. Pada tahun 2013 angka cakupan imunisasi dasar lengkap sebesar 90,4\%, tahun 2014 sebesar $119 \%$ dan pada tahun 2015 sebesar 82,1\%.

Dalam profil Puskesmas Gayam dinyatakan bahwa untuk menunjang program imunisasi di wilayah kerja Puskesmas Gayam, telah ditunjuk 8 bidan desa yang tersebar di berbagai desa. Selain itu, Puskesmas juga menunjuk kader kesehatan sebanyak 173 orang yang tersebar di setiap desa. Penunjukan kader tersebut bertujuan untuk membantu seluruh kegiatan program Puskesmas Gayam termasuk imunisasi. Berdasarkan informasi tersebut dapat diketahui bahwa pelaksanaan program imunisasi di setiap desa sudah baik dengan adanya bidan desa dan bantuan kader kesehatan terkait program imunisasi. Namun, pada kenyataannya di tahun 2015 capaian imunisasi dasar lengkap pada bayi mengalami penurunan hingga mencapai $82,1 \%$. Angka tersebut menunjukan penurunan yang jauh dibawah standar target renstra program imunisasi (91\%). (Puskesmas Gayam, 2016).

Laporan Puskesmas Gayam tersebut menyatakan terdapat kasus pertusis sebesar 3 kasus selama tahun 2015. Kasus pertusis tersebut merupakan kasus yang pertama kali ditemukan di wilayah kerja Puskesmas Gayam sejak 5 tahun terakhir (Puskemas Gayam, 2016).

Peran bidan desa dan kader kesehatan dalam melaksanakan kegiatan program imunisasi di Puskesmas Gayam sudah baik. Hal ini ditandai dengan pelaksanaan program dan laporan bulanan dilakukan dengan tepat waktu. Meskipun kegiatan program imunisasi sudah baik, akan tetapi capaian imunisasi menunjukkan angka penurunan bahkan dibawah standar. Hal ini menandakan ada faktor lain yang memungkinkan penurunan pencapaian imunisasi dasar lengkap.

Berdasarkan penelitian sebelumnya, terdapat banyak faktor yang mempengaruhi status imunisasi. Faktor tersebut diadopsi dari konsep Lawrence Green dalam (Notoatmodjo, 2010) diantaranya faktor predisposisi (faktor ibu), faktor pemungkin (faktor fasilitas kesehatan) dan faktor pendorong/penguat (faktor petugas kesehatan, dukungan keluarga dan dukungan masyarakat).

Faktor predisposisi yang dikemukakan oleh peneliti sebelumnya seperti Ikawati (2011), Rahmawati (2013) dan Oktaviani (2015). Menurut Rahmawati (2013) menyatakan faktor predisposisi yang mempengaruhi ketidaklengkapan imunisasi yaitu faktor tradisi. Sedangkan pada penelitian dari Ikawati (2011) menyatakan bahwa faktor predisposisi yang mempengaruhi status imunisasi pada bayi adalah pekerjaan ibu dan pengetahuan ibu. Hasil yang sama dikemukakan oleh Oktaviani (2015) bahwa faktor predisposisi yang mempengaruhi penolakan pemberian imunisasi adalah faktor tingkat pengetahuan ibu dan sikap ibu.

Berdasarkan faktor penguat yang diadopsi dari konsep Lawrence Green, para peneliti mengemukakan ada pengaruh antara dukungan keluarga dengan status imunisasi. Pendapat tersebut dikemukakan oleh Rahmawati (2013) dan Oktaviani (2015).

Berdasarkan penelitian terdahulu, faktor predisposisi (faktor ibu) merupakan faktor terbanyak yang mempengaruhi status imunisasi. Hal ini menandakan faktor predisposisi lebih berperan dalam pencapaian status imunisasi pada anak.

Puskesmas Gayam telah menjalankan program imunisasi dengan baik. Peran bidan desa dan kader kesehatan membantu penuh dalam kegiatan imunisasi, akan tetapi angka cakupan imunisasi mengalami penurunan dan ditemukan kasus PD3I di tahun 2015. Faktor yang memungkinkan untuk terjadinya permasalahan tersebut adalah faktor ibu. Hal ini dikarenakan faktor petugas kesehatan dan dukungan masyarakat melalui kader telah berjalan dengan baik.

Menurut Notoatmodjo (2003) menyatakan bahwa perilaku manusia dibagi 3 domain yakni kognitif, afektif dan psikomotorik. Teori ini kemudian dimodifikasi untuk pengukuran pendidikan kesehatan menjadi 3 domain baru yaitu pengetahuan, sikap dan tindakan. Pada 
penelitian ini dilakukan pengukuran faktor ibu dalam ketiga domain tersebut.

Tujuan penelitian ini adalah mendeskripsikan dan menganalisis faktor ibu yang hubungan dengan perilaku ibu dalam capaian imunisasi dasar lengkap pada bayi di wilayah kerja Puskesmas Gayam.

\section{METODE}

Penelitian ini menggunakan rancangan cross sectional. Populasi dalam penelitian ini adalah ibu yang memiliki balita berusia 12-24 bulan di beberapa wilayah kerja Puskesmas Gayam yang menunjukan jumlah cakupan imunisasi dasar lengkap menurun dari tahun sebelumnya dan belum mencapai target renstra indikator program imunisasi dari Kemenkes RI yaitu Desa Gayam, Desa Pancor, Desa Gendang Timur, Desa Karang Tengah, Desa Tarebung dan Desa Gendang Barat. Jumlah popolasi pada penelitian ini sebesar 237 ibu. Kriteria inklusi yang ditetapkan adalah ibu dengan anak balita yang memiliki buku KMS/KIA dan bersedia untuk diwawancarai. Besar sampel pada penelitian adalah 144 responden. Pemilihan sampel dilakukan dengan cara simple random sampling. Sumber data penelitian ini dengan menggunakan data primer yaitu kuesioner yang dibacakan pada resonden. Variabel yang dianalisis adalah usia, tingkat pendidikan, pekerjaan, tingkat pendidikan, kepercayaan dan sikap ibu. Analisis data menggunakan analisis bivariat Chi-Square untuk mengetahui hubungan antara variabel independen dengan variabel dependen dengan melihat nilai $\mathrm{p}<0,05$.

\section{HASIL dan PEMBAHASAN}

Deskripsi Karateristik, Pengetahuan, Kepercayaan dan Sikap Ibu

\section{Karakteristik Ibu}

\section{a. Usia Ibu}

Usia ibu pada penelitian ini berada pada rentang usia 21 tahun hingga 57 tahun. Usia responden termuda yaitu 21 tahun $(3,5 \%)$ dan usia responden tertua adalah 57 tahun $(0,7 \%)$. Rerata dari usia responden yaitu berkisar umur 30 tahun. Distribusi usia responden sebagai berikut :

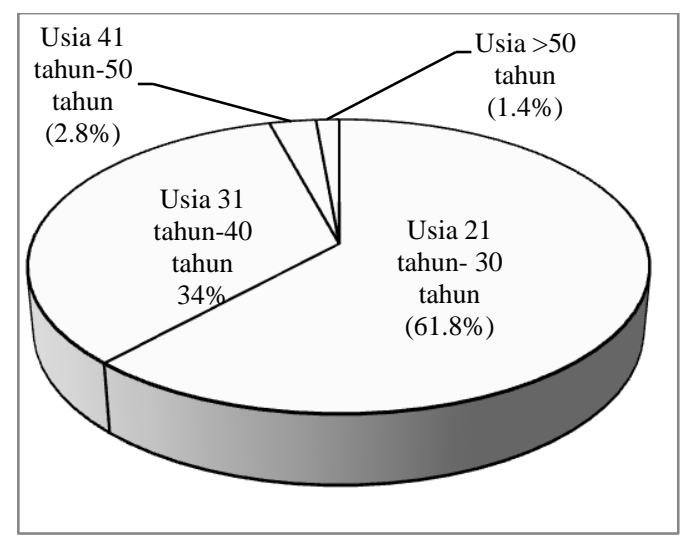

Gambar 1. Distribusi usia ibu di wilayah kerja Puskesmas Gayam

Berdasarkan Gambar 1 didapatkan data distribusi umur ibu terbanyak yaitu umur $\leq 30$ tahun $(61,8 \%)$. Hasil sama juga didiapatkan pada penelitian dari Oktaviani (2015) yang menyatakan bahwa karakteristik umur responden paling banyak yaitu kelompok umur $\leq 30$ tahun. Penelitian Oktaviani dilakukan di Puskesmas Kamoning Kabupaten Sampang. Hasil penelitian ini menandakan terdapat kesamaan karakteristik ibu dengan penelitian Oktaviani. Hal ini kemungkinan disebabkan oleh adanya kesamaan daerah antara Kabupaten Sumenep dan Kabupaten Sampang. Faktor umur merupakan faktor yang penting, karena umur dapat mempengaruhi pengalaman seseorang dalam menangani masalah kesehatan/penyakit serta pengambilan keputusan (Noor, 2000).

\section{b. Tingkat pendidikan ibu}

Tingkat pendidikan ibu beragam mulai dari tidak sekolah/tidak tamat SD hingga tamat perguruan tinggi. Tingkat pendidikan dengan kategori tamat SD/Sederajat merupakat tingkat pendidikan terbanyak dalam penelitian ini $(31,9 \%)$. Pendidikan tamat perguruan tinggi masih rendah $(13,9 \%)$. Selain itu masih terdapat ibu dengan tingkat pendidikan yang belum tamat sekolah/tidak tamat SD. Distribusi tingkat pendidikan ibu sebagai berikut: 


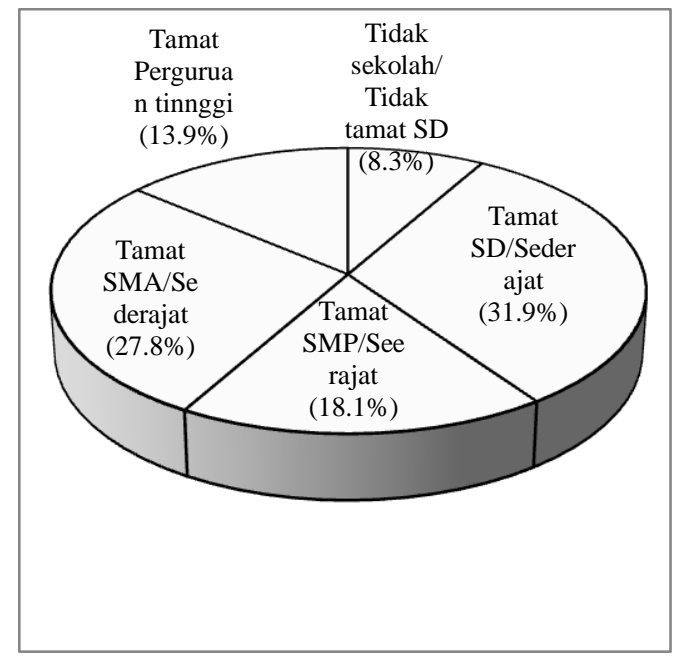

Gambar 2. Distribusi tingkat pendidikan ibu di wilayah kerja Puskesmas Gayam

Distribusi pendidikan ibu berkisar mulai dari tidak pernah sekolah/tidak tamat SD hingga tamat perguruan tinggi. Berdasarkan Gambar 2 didapatkan data tingkat pendidikan ibu $\leq 9$ tahun atau minimal tamat SMP/Sederajat sebanyak $58,3 \%$. Hasil yang sama dikemukakan oleh Oktaviani (2015) bahwa tingkat pendidikan responden mayoritas menempuh pendidikan $\leq 9$ tahun di wilayah kerja Puskesmas Kamoning Kabupaten Sampang. Hasil ini sama dengan yang diperoleh pada faktor umur, dengan demikian ada kesamaan antara karakteristik ibu di Kabupaten Sumenep dan Kabupaten Sampang terkait tingkat pendidikan ibu. Selain itu, berdasarkan Gambar 2 dapat diketahui distribusi terbanyak tingkat pendidikan ibu adalah tamat $\mathrm{SD} /$ sederajat $(31,9 \%)$. Hasil penelitian ini mempunyai kesamaan dengan penelitian Oktaviani (2015) bahwa distribusi terbanyak tingkat pendidikan di Puskesmas Kamoning Kabupaten Sampang yaitu responden dengan tamat SD $(72,5 \%)$.

Penelitian ini memiliki perbedaan dengan penelitian Rahmawati (2013) di Kelurahan Krembangan Utara Kota Surabaya yang menyatakan bahwa tingkat pendidikan terbanyak yaitu pendidikan menengah atas $(65,2 \%)$. Perbedaan tersebut kemungkinan disebabkan karena unsur perbedaan daerah. Pada penelitian ini dilakukan di Kecamatan Gayam Kabupaten
Sumenep, sedangkan pada penelitian Rahmawati dilakukan di Kota Surabaya.

Penelitian Ikawati (2011) menyatakan bahwa mayoritas ibu memiliki tingkat pendidikan menengah. Penelitian Ikawati ini dilakukan di Kelurahan Banyuanyar Kabupaten Sampang.

\section{c. Pekerjaan ibu}

Responden yang bekerja lebih banyak daripada yang tidak bekerja. Jenis pekerjaan ibu adalah petani, pegawai honorer, peternak, pedagang, pegawai swasta, PNS dan Wiraswasta. Distribusi jenis pekerjaan ibu yang terbanyak adalah sebagai petani $(25 \%)$ sebagaimana disampaikan pada Gambar 3 sebagai berikut :

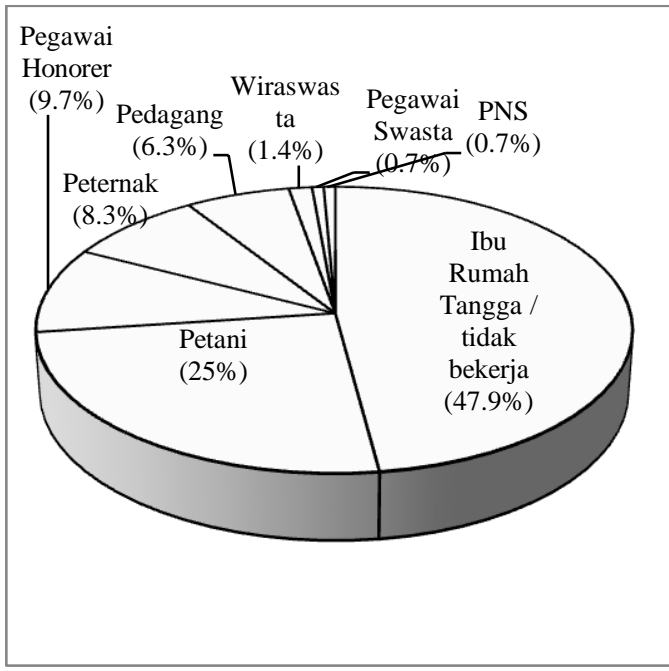

Gambar 3. Distribusi jenis pekerjaan ibu di wilayah kerja Puskesmas Gayam

Berdasarkan pekerjaan ibu, menurut Gambar 3 didapatkan data distribusi ibu bekerja lebih banyak dengan persentase $52,1 \%$. Jenis pekerjaan terbanyak adalah petani bagi ibu dengan kategori bekerja. Penelitian ini memiliki kesamaan dengan Oktaviani (2015) bahwa distribusi paling banyak ibu bekerja sebagai petani di wilayah kerja Puskesmas Kamoning Kabupaten Sampang. Penelitian ini memiliki kesamaan karakteristik responden dengan penelitian Oktaviani pada bidang pekerjaan, hal ini kemungkinan disebabkan oleh kultur daerah yang sama di Pulau Madura. 


\section{Tingkat pengetahuan ibu}

Tingkat pengetahuan ibu didapatkan dari hasil jawaban ibu terhadap kuesioner yang telah dibacakan oleh peneliti. Penelitian ini menunjukkan bahwa mayoritas ibu berpengetahuan rendah atau buruk $(59,0 \%)$. Distribusi frekuensi tingkat pengetahuan ibu adalah ibu dengan tingkat pengetahuan baik (jawaban benar $\geq 76 \%$ ) sebanyak 17 orang $(11,8 \%)$, ibu yang memiliki tingkat pengetahuan sedang (jawaban benar 56\%-75\%) sebanyak 42 orang $(29,2 \%)$, dan ibu yang me miliki tingkat pengetahuan buruk (jawaban benar $\leq 55 \%)$ sebanyak 85 orang (59\%). Mayoritas ibu menjawab benar pertanyaan mengenai pengertian dan manfaat imunisasi. Jawaban pertanyaan yang menjadi jawaban terbanyak terkait jenis dan jadwal imunisasi adalah imunisasi BCG, Campak dan Polio.

Berdasarkan faktor tingkat pengetahuan ibu tentang imunisasi, tingkat pengetahuan kurang memiliki presentasi lebih banyak (59\%) dibanding ibu dengan pengetahuan baik maupun sedang. Penelitian ini berbeda dengan Rahmawati (2013) yang menemukan tidak ada perbedaan antara tingkat pengetahuan responden tentang imunisasi yang terbagi rata $50 \%$. Perbedaan penelitian ini kemungkinan disebabkan oleh unsur wilayah penelitian. Penelitian Rahmawati dilakukan di Kota Surabaya sedangkan penelitian ini dilakukan di Kecamatan Gayam Kabupaten Sumenep. Namun hasil penelitian ini sama dengan penelitian Oktaviani (2015) yang juga melakukan penelitian di wilayah wilayah kerja Puskesmas Kamoning Kabupaten Sampang yang menunjukan mayoritas responden memiliki pengetahuan kurang lebih banyak $(57,5 \%)$.

\section{Kepercayaan ibu}

Kepercayaan ibu dikelompokkan menjadi dua kategori yaitu percaya dan tidak percaya. Hasil penelitian menunjukkan bahwa mayoritas ibu percaya terhadap program imunisasi. Distribusi kepercayaan ibu adalah ibu dengan percaya terhadap program imunisasi sebanyak 106 orang $(73,6 \%)$ dan ibu yang tidak mempercayai program imunisasi yaitu sebanyak 38 orang $(26,4 \%)$. Alasan terbanyak ibu mempercayai program imunisasi adalah membuat bayi sehat dan terhindar dari penyekit. Sedangkan alasan terbanyak ibu tidak mempercayai program imunisasi adalah anak menjadi sakit dan ibu mempunyai rasa takut panas pada anak.

Berdasarkan faktor kepercayaan ibu didapatkan data distribusi kepercayaan ibu dengan status ibu yang percaya terhadap program imunisasi lebih banyak dibanding ibu yang tidak percaya, persentase ibu ibu percaya terhadap imunisasi yaitu $73,6 \%$. Hasil penelitian ini memiliki kesamaan dengan Rahmawati (2013) bahwa balita yang memiliki status imunisasi lengkap tidak percaya bahwa imunisasi memberikan dampak buruk sebesar 70,5\% . Hal ini berarti bahwa ibu dengan presentase sebesar $70,5 \%$ percaya bahwa imunisasi memberikan dampak baik pada bayi atau balita.

\section{Sikap ibu}

Sikap ibu didapatkan dari hasil jawaban ibu dalam kuesioner yang telah dibacakan oleh peneliti. Hasil ini menandakan bahwa mayoritas ibu memiliki sikap yang baik dari pada sikap yang kurang baik. Sikap ini menandakan bahwa sebagaian besar ibu kemungkinan mengimunisasi anaknya. Distribusi sikap ibu adalah ibu yang memiliki sikap baik sebanyak 78 orang $(54,2 \%)$ dan ibu yang mempunyai sikap kurang baik sebanyak 66 orang $(45,8 \%)$.

Berdasarkan faktor sikap ibu didapatkan data bahwa ibu dengan status sikap yang baik menunjukkan jumlah yang lebih banyak dibanding ibu dengan sikap ibu yang kurang baik, persentase ibu bersikap baik yaitu 54,2\%. Hasil yang sama didapatkan dalam penelitian dari Oktaviani (2015) yang menyatakan bahwa sebagian besar responden memiliki sikap baik sebesar $55 \%$.

\section{Hubungan antar variabel}

1) Hubungan Karakteristik (Usia, Tingkat Pendidikan dan Pekerjaan ibu) dengan Pencapaian Imunisasi Dasar Lengkap 
Tabel 1. Hubungan karakteristik (usia, tingkat pendidikan dan pekerjaan ibu) dengan pencapaian imunisasi dasar lengkap pada bayi di wilayah kerja Puskesmas Gayam

\begin{tabular}{|c|c|c|c|c|c|c|c|}
\hline \multirow{3}{*}{$\begin{array}{l}\text { Karak- } \\
\text { teristik } \\
\text { ibu }\end{array}$} & \multicolumn{4}{|c|}{ Status Imunisasi } & \multirow{2}{*}{\multicolumn{2}{|c|}{ Total }} & \multirow{3}{*}{$\begin{array}{c}p \\
\text { value }\end{array}$} \\
\hline & \multicolumn{2}{|c|}{ Lengkap } & \multicolumn{2}{|c|}{$\begin{array}{c}\text { Tidak } \\
\text { Lengkap }\end{array}$} & & & \\
\hline & $\mathrm{n}$ & $\%$ & $\mathrm{n}$ & $\%$ & $\mathrm{n}$ & $\%$ & \\
\hline \multicolumn{8}{|l|}{ Usia } \\
\hline $\begin{array}{l}\leq 30 \\
\text { tahun }\end{array}$ & 49 & 55,1 & 40 & 44,9 & 89 & 100 & \multirow{2}{*}{0,754} \\
\hline $\begin{array}{l}>30 \\
\text { tahun }\end{array}$ & 28 & 50,9 & 27 & 49,1 & 55 & 100 & \\
\hline
\end{tabular}

\begin{tabular}{|c|c|c|c|c|c|c|c|}
\hline \multicolumn{8}{|c|}{ Tingkat pendidikan } \\
\hline $\begin{array}{l}\text { Pendidi } \\
\text { kan } \\
\text { tinggi } \\
(> \\
\text { SMA) }\end{array}$ & 16 & 80 & 4 & 20 & 20 & 100 & \multirow{2}{*}{$\begin{array}{c}0,02 \\
0\end{array}$} \\
\hline $\begin{array}{l}\text { Pendidi } \\
\text { kan } \\
\text { rendah } \\
(\leq \\
\text { SMA })\end{array}$ & 61 & 49,2 & 63 & 50,8 & $\begin{array}{c}12 \\
4\end{array}$ & 100 & \\
\hline \multicolumn{8}{|c|}{ Pekerjaan } \\
\hline Bekerja & 38 & 50,7 & 37 & 49,3 & 60 & 100 & \multirow{2}{*}{$\begin{array}{c}0,59 \\
2\end{array}$} \\
\hline $\begin{array}{l}\text { Tidak } \\
\text { Bekerja }\end{array}$ & 39 & 56,5 & 30 & 43,5 & 84 & 100 & \\
\hline
\end{tabular}

\section{a. Usia Ibu}

Berdasarkan hasil penelitian, ibu yang berusia $\leq 30$ tahun memiliki status imunisasi lengkap lebih banyak dari pada ibu dengan status imunisasi tidak lengkap. Hasil yang sama juga terdapat pada ibu yang berusia > 30 tahun. Walaupu ibu dengan usia >30 tahun memiliki proporsi yang hampir sama antara ibu yang mengimunisasikan anaknya secara lengkap dan ibu yang tidak mengimunisasikan anaknya secara lengkap. Hasil penelitian menunjukan tidak ada hubungan antara usia ibu dengan pencapaian imunisasi dasar lengkap $(\mathrm{p}=0,754)$.

Hasil penelitian ini sesuai dengan penelitian Rini (2009) bahwa tidak memiliki hubungan antara faktor umur dengan status imunisasi pada bayi di Kelurahan Wonokusumo Kecamatan Semampir Surabaya. Penelitian ini memiliki kesamaan dengan penelitian Rini, meskipun berdasarkan wilayah penelitian berbeda akan tetapi berdasarkan umur responden tidak jauh beda antara penelitian yang dilakukan di Kecamatan Gayam Kabupaten Sumenep dan penelitian yang dilakukan di Kelurahan Wonokusumo Kecamatan Semampir Surabaya. Penelitian ini berbeda dengan Satoto dalam Rizqiawan (2008) yang menyatakan bahwa peningkatan usia ibu dapat menambah pengalaman ibu dalam mengurus dan mengasuh anak, sehingga dapat mencegah dan menanggulangi terjadinya penyakit pada anak. Pernyataan tersebut menandakan bahwa semakin matang usia ibu makan akan menambah pengalaman ibu tersebut dalam melakukan upaya preventif bagi anaknya termasuk mengimunisasikan anakanya secara lengkap. Maka dari itu usia merupakan salah satu faktor yang penting yang dimiliki oleh ibu dalam pencapaian imunisasi anaknya. Usia merupakan karakteristik seseorang yang berhubungan dengan sifat dalam dirinya serta sifat dalam menentukan tempat dan waktu (Noor, 2000).

\section{b. Tingkat Pendidikan Ibu}

Berdasarkan hasil penelitian, ibu dengan pendidikan tinggi memiliki status imunisasi lengkap lebih banyak dari pada ibu dengan status imunisasi tidak lengkap. Hasil berbeda terdapat pada ibu yang dengan pendidikan rendah. Ibu dengan pendidikan rendah melakukan imunisasi tidak lengkap dan imunisasi lengkap hampir sama. Hasil penelitian menunjukan terdapat hubungan antara tingkat pendidikan ibu dengan pencapaian imunisasi dasar lengkap $(\mathrm{p}=0,020)$.

Hasil ini memiliki kesamaan dengan penelitian Ningrum (2008) bahwa tingkat pendidikan ibu memiliki hubungan dengan status imunisasi dasar pada bayi. Pendidikan yang tinggi memiliki pengaruh positif terhadap kelengkapan imunisasi dasar pada bayi. Namun ningrum (2008) tidak menyebutkan jumlah distribusi tingkat pendidikan responden, Ningrum hanya menyebutkan adanya pengaruh tingkat pendidikan. Penelitian Ningrum dilakukan di Puskesmas Banyudona Kabupaten Boyolali. Pendapat yang sama juga dikemukakan oleh Idwar (2000) bahwa tingkat pendidikan ibu yang tinggi memiliki peluang untuk mengimunisasikan anaknya secara lengkap. Penelitian idwar 
dilakukan di Kabupaten Aceh Besar. Berdasarkan penelitian Ningrum dan Idwar dilakukan di tempat yang berbeda begitupula pada penelitian ini. Hal ini menandakan bahwa tingkat pendidikan ibu meurpakan salah satu faktor dalam kelengkapan status imunisasi anak.

Penelitian ini berbeda dengan penelitian Ikawati (2011) yang menyatakan bahwa tingkat pendidikan ibu tidak berpengaruh dengan kelengkapan imunisasi dasar pada bayi. Hasil ini juga berbeda dengan peneilitan Rahmawati (2013) yang menyatakan bahwa faktor tingkat pendidikan ibu tidak memiliki pengaruh berarti dengan kelengkapan imunisasi pada bayi. Pada penelitian Rahmawati menunjukkan hasil berbeda pula pada deskripsi tingkat pendidikan. Hal ini menandakan bahwa tingkat pendidikan ibu di Kecamatan Gayam Kabupaten Sumenep berbeda dengan tingkat pendidikan di Kelurahan Krembangan Utara Kota Surabaya. Perbedaan tersebut dikarenakan oleh adanya perbedaan daerah penelitian.

Penelitian ini menunjukkan hasil mayoritas responden dengan tamat SD. Pendidikan yang rendah tersebut dijadikan suatu acuan untuk para bidan desa dan kader dalam menjalankan program imunisasi. Cara dalam melakukan pemberian program promosi kesehatan harus disesuaikan dengan karakter tingkat pendidikan di daerah tersebut.

Pendidikan merupakan salah satu proses perubahan perilaku. Apabila seseorang memiliki tingkat pendidikan yang tinggi maka orang tersebut akan memperhitungkan tempat-tempat pelayanan kesehatan dalam kehidupannya (Rini, 2009). Seseorang dengan tingkat pendidikan tinggi kemungkinan akan berfikir kearah preventif seperti mengimunisasikan anaknya. Tingkat pendidikan juga dapat memiliki peran untuk mengetahui tingkat pengetahuan seseorang. Menurut Ali dalam Rini (2009) menyatakan bahwa pengetahuan seseorang memungkinkan untuk terjadinya perubahan perilaku, karena pengetahuan diperoleh dari pendidikan, pengamatan dan informasi.

Salah satu faktor ibu dalam melakukan imunisasi anaknya yaitu faktor tingkat pendidikan ibu tersebut. Pendidikan yang dimiliki oleh ibu merupakan pondasi yang menunjang tingkat pengetahuan ibu (Risnawati, 2014). Namun seseorang yang berpendidikan rendah belum tentu mempunyai pengetahuan yang yang rendah pula, karena pengetahuan tidak hanya diperoleh dari pendidikan formal tetapi juga dapat diperoleh dari pendidikan non formal.

\section{c. Pekerjaan Ibu}

Berdasarkan hasil penelitian, ibu dengan status bekerja memiliki proporsi hampir sama antara status imunisasi lengkap dan tidak lengkap. Hasil berbeda terdapat pada ibu dengan status tidak bekerja. Ibu dengan status tidak bekerja cenderung mengimunisasikan anaknya. Sehingga ibu dengan status bekerja melakukan imunisasi lengkap lebih banyak daripada imunisasi tidak lengkap. Hasil penelitian menunjukan tidak terdapat hubungan antara pekerjaan ibu dengan pencapaian imunisasi dasar lengkap ( $\mathrm{p}=$ 0,592).

Penelitian ini sesuai dengan Ari Prayogo dkk (2009) bahwa pekrjaan ibu tidak memiliki hubungan dengan imunisasi dasar lengkap pada anak. Selain itu, penelitian ini juga didukung oleh penelitian Ikawati (2011) yaitu menyatakan bahwa tidak ada pengaruh antara pekerjaan ibu dengan status imunisasi dasar lengkap pada bayi di Kelurahan Banyuanyar Kabupaten Sampang.

Penelitian ini menunjukan mayoritas ibu bekerja sehingga memungiinkan banyak yang tidak mengimunisasikan anaknya. Menurut Depkes RI (2000) menyatakan bahwa kebanyakan ibu yang tidak mengimunisasikan anaknya dengan alasan sibuk dengan pekerjaannya. Kebanyakan ibu yang bekerja diluar rumah kurang memeperhatikan keadaan anaknya dikarenakan ibu mendapatkan beban baru selain mengurus anak. Sehingga ibu tidak dapat mengikuti pertumbuhan dan perkembangan anaknya termasuk kebutuhan anakanya untuk mendapatkan imunisasi.

Hasil penelitian ini berbeda dengan penelitian Idwar dalam Utami (2008) yang menyatakan bahwa Ibu yang bekerja mempunyai risiko lebih besar untuk mengimunisasikan bayinya dibandingkan 
dengan ibu yang tidak bekerja atau ibu rumah tangga. Ibu yang bekerja cenderung mendapatkan informasi yang banyak dibandingkan dengan ibu yang tidak bekerja hanya sebagai ibu rumah tangga.

Depkes RI (2000) menyatakan terjadinya peralihan dari masyarakat agraris dan industri menyebabkan sebagian besar terjun ke lapangan kerja informal. Semakin meningkatnya pekerja wanita baik di sektor formal maupun informal, tentunya aktifitas ibu yang bekerja akan berpengaruh terhadap waktu yang dimiliki ibu untuk memberikan upaya preventif pada anaknya seperti pemberian imunisasi (Rini, 2009). Pekerjaan formal seperti perkantoran dan pegawai negeri membutuhkan ijazah untuk mendapatkan tempat bekerja. Hal ini memungkinkan tingkat pendidikan ibu dapat mempengaruhi status pekerjaan ibu, karena faktor pekerjaan ibu tidak dapat berdiri sendiri dalam kelengkapan imunisasi pada bayi.

\section{2) Hubungan Tingkat Pengetahuan Ibu dengan Pencapaian Imunisasi Dasar Lengkap}

Berdasarkan hasil penelitian, ibu yang memiliki pengetahuan baik dan pengetahuan sedang mendapatkan proporsi status imunisasi lengkap lebih banyak daripada proporsi dengan status imunisasi lengkap. Hal ini menandakan bahwa pengetahuan imu memungkinkan untuk ibu berperilaku positif dalam melakukan imunisasi. Hasil berbeda terdapat pada ibu yang memiliki pengetahuan kurang. Ibu dengan pengetahuan kurang cenderung tidak mengimunisasikan anaknya. Sehingga proporsi ibu melakukan imunisasi lengkap lebih seidikit daripada imunisasi tidak lengkap.

Tabel 2. Hubungan tingkat pengetahuan ibu dengan pencapaian imunisasi dasar lengkap pada bayi di wilayah kerja Puskesmas Gayam

\begin{tabular}{|c|c|c|c|c|c|c|c|}
\hline \multirow{3}{*}{$\begin{array}{c}\text { Ting- } \\
\text { kat } \\
\text { Penge- } \\
\text { tahuan } \\
\text { Ibu }\end{array}$} & \multicolumn{4}{|c|}{ Status Imunisasi } & \multirow{2}{*}{\multicolumn{2}{|c|}{ Total }} & \multirow{3}{*}{ p value } \\
\hline & \multicolumn{2}{|c|}{ Lengkap } & \multicolumn{2}{|c|}{$\begin{array}{c}\text { Tidak } \\
\text { Lengkap }\end{array}$} & & & \\
\hline & $\mathrm{n}$ & $\%$ & $\mathrm{n}$ & $\%$ & $\mathrm{n}$ & $\%$ & \\
\hline Baik & 15 & 88,2 & 2 & 11,8 & 17 & 100 & \multirow{3}{*}{0,000} \\
\hline Sedang & 32 & 76,2 & 10 & 23,8 & 42 & 100 & \\
\hline Kurang & 30 & 35,3 & 55 & 64,7 & 85 & 100 & \\
\hline
\end{tabular}

Hasil penelitian menunjukan ada hubungan antara tingkat pengetahuan ibu dengan pencapaian imunisasi dasar lengkap $(\mathrm{p}=0,000)$.

Hasil yang diperoleh dari penelitian ini sama dengan yang diperoleh pada penelitian sebelumnya yang dilakukan oleh Ikawati (2011), Dewi dkk (2013) dan Oktaviani (2015). Pada penelitian ini tingkat pengetahuan ibu mempunyai kesamaan hasil dengan penelitian dari Oktaviani dan Ikawati. Kedua peneliti tersebut melakukan penelitiannya di Kabupaten Sampang. Hal ini menandakan bahwa tidak ada beda tingkat pengetahuan ibu di wilayah madura khususnya Kabupaten Sumenep dan Kabuaten Sampang. Berdasarkan penelitian yang dikemukakan oleh Dewi dkk di Kota Padang menunjukkan hasil sama dengan penelitian ini. Hal ini menandakan bahwa faktor tingkat pengetahuan ibu merupakan salah satu faktor penting dalam pencapaian imunisasi dasar pada bayi.

Penelitian ini bertentangan dengan Rahmawati (2013) yang menyatakan bahwa tingkat pengetahuan ibu tidak berpengaruh terhadap kelengkapan status imunisasi pada bayi. Selain itu hasil yang sama juga dikemukakan oleh Risnawati (2014) yang menyatakan bahwa tingkat pengetahuan ibu tidak memiliki pengaruh terhadap status imunisasi dasar lengkap pada bayi. Selaras dengan penelitian keduanya, Delan (2011) juga menyatakan bahwa tingkat pengetahuan ibu tidak memiliki berhubungan bermakna dengan status imunisasi dasar lengkap pada anak. Penelitian dari Rahmawati dan Risnawati dilakukan di Kota Surabaya, hal ini memungkinkan perbedaan tingkat pengetahuan dengan penelitian ini. Responden yang berada di Kota Surabaya memungkinkan untuk mendapatkan informasil lebih terkait beberapa hal termasuk pengetahuan tentang imunisasi. Sehingga hal ini menjadi berbeda dengan responden yang berda di daerah desa ataupun kepulauan.

Hasil penelitian ini memberikan informasi bahwa ibu dengan tingkat pengetahuan sedang dan tingkat pengetahuan kurang tidak memiliki perbedaan yang mencolok dalam mengimunisasikan anaknya secara lengkap. 
Hal ini didapatkan karena mayoritas ibu mendapat dorongan dari bidan desa, kader dan keluarganya untuk mengimunisasikan anaknya. Dorongan ini merupakan dukungan sosial (social support) dalam bentuk dukungan informatif. Menurut House dalam Smet (1994) menyatakan bahwa social support dibedakan menjadi empat bentuk dukungan yaitu dukungan emosional, dukungan instrumental, dukungan penghargaan dan dukungan informatif.

Pada penelitian ini didapatkan bahwa mayoritas pengetahuan ibu dengan tingkat pengetahuan kurang. Hal ini kemungkinan di pengaruhi oleh faktor lainnya yaitu faktor tingkat pendidikan. Hasil penelitian ini menunjukkan bahwa mayoritas ibu memiliki tingkat pendidikan yang rendah dan juga memiliki tingkat pengetahuan yang rendah. Hasil ini memungkinkan adanya hubungan yang erat antara pendidikan ibu dengan pengetahuan ibu. Sehingga faktor pengetahuan tidak berdiri sendiri, akan tetapi didukung oleh faktor lain dalam pencapaian imunisasi dasar lengkap pada bayi. Pengetahuan yang kurang memungkinkan untuk tidak lengkapnya imunisasi anak. Hal ini menjadi perhatian khusus dalam peningkatan pencapaian imunisasi dasar lengkap. Peran petugas kesehatan dan kader menjadi penting dalam pelaksanaan program dilapangan.

Program imunisasi akan menunjukkan keberhasilan apabila ada usaha dan komitmen yang tinggi terhadap imunisasi. Apabila program imunisasi ingin dilaksanakan secara serius dalam mengatasi penyakit PD3I maka dibutuhkan peningkatan pengerahuan ibu dan evaluasi perilaku kesehatan masyarakat (Ali dalam Rini, 2009).

Ibu yang mengetahui pentingnya pemberian imunisasi dasar lengkap sebagai bentuk pencegahan (preventif) agar terhindar dari penyakit dan menyehatkan tubuh sang anak menyebabkan kecendrungan berperilaku baik dalam pemberian imunisasi. Ibu tersebut akan berupaya untuk selalu memberikan imunisasi kepada anaknya sesuai dengan jadwal imunisasi yang diberikan oleh petugas kesehatan. Menurut Notoatmodjo (2014) perilaku seseorang akan melekat dan bertahan lama jika perilaku tersebut didasari oleh pengetahuan. Pengetahuan merupakan hasil pengindraan manusia atau hasil tahu seseorang terhadap suatu objek tertentu. Pengetahuan manusia pada dasarnya banyak diperoleh dari indra penglihatan dan pendengaran (Notoatmodjo, 2010).

Peran Puskesmas Gayam melalui kader kesehatan dan pemegang program imunisasi merupakan faktor utama dalam penambahan informasi terhadap ibu sehingga pengetahuan ibu dapat meningkat. Menurut Puksemas Gayam (2016) menyatakan bahwa terdapat 173 kader kesehatan dan 8 orang bidan desa yang akan membantu tercapaianya imunisasi dasar lengkap di wilayah kerja Puskesmas Gayam.

Berdasarkan penelitian ini faktor pengetahuan tidak serta merta berdiri sendiri dan berpengaruh dalam pencapaian imunisasi dasar lengkap pada bayi. Namun ada beberapa faktor yang dapat mempengaruhi pencapaian imunisasi. Sama halnya dengan pencapaian imunisasi. Faktor pengetahuan dapat dipengaruhi oleh faktor umur, pendidikan dan pengalaman (Notoadmojo, 2003).

Distribusi umur menunjukan angka tebanyak yaitu umur $\leq 30$ tahun. Hal ini menandakan bahwa dengan umur yang relatif masih muda akan memungkinkan untuk ibu mendapatkan suatu pembelajaran mengenai imunisasi . sehingga dapat menyebabkan pengetahun akan imunisasi meningkat dikemudian hari. Selain umur, faktor pendidikan juga dapat mempengaruhi pengetahuan. Semakin tinggi pendidikan seseorang, maka semakin mudah orang tersebut menerima informasi, sehingga semakin banyak juga pengetahuan yang dimiliki. Sebaliknya, pendidikan yang kurang akan menghambat perkembangan sikap seseorang terhadap sesuatu yang baru (Mubarak, 2006).

\section{3) Hubungan Kepercayaan Ibu dengan Pencapaian Imunisasi Dasar Lengkap}

Berdasarkan hasil penelitian, ibu yang percaya terhadap program imunisasi mendapatkan proporsi status imunisasi lengkap lebih banyak daripada proporsi dengan status imunisasi tidak lengkap. Hal 
ini memungkinkan ibu untuk berperilaku selalu mengimunisasikan anaknya. Hasil berbeda terdapat pada ibu yang tidak percaya terhadap program imunisasi. Ibu yang tidak percaya terhadap imunisasi cenderung tidak mengimunisasikan anaknya. Sehingga proporsi ibu melakukan imunisasi lengkap lebih sedikit daripada imunisasi lengkap.

Tabel 3. Hubungan kepercayaan ibu dengan pencapaian imunisasi dasar lengkap pada bayi di wilayah kerja Puskesmas Gayam

\begin{tabular}{|c|c|c|c|c|c|c|c|}
\hline \multirow{3}{*}{$\begin{array}{c}\text { Keper- } \\
\text { cayaan } \\
\text { Ibu }\end{array}$} & \multicolumn{4}{|c|}{ Status Imunisasi } & \multirow{2}{*}{\multicolumn{2}{|c|}{ Total }} & \multirow{3}{*}{$\begin{array}{c}p \\
\text { value }\end{array}$} \\
\hline & \multicolumn{2}{|c|}{ Lengkap } & \multicolumn{2}{|c|}{$\begin{array}{c}\text { Tidak } \\
\text { Lengkap }\end{array}$} & & & \\
\hline & $\mathrm{n}$ & $\%$ & $\mathrm{n}$ & $\%$ & $\mathrm{n}$ & $\%$ & \\
\hline $\begin{array}{l}\text { Percaya } \\
\text { terhadap } \\
\text { imunisasi }\end{array}$ & 69 & 65,1 & 57 & 34,9 & 106 & 100 & \\
\hline $\begin{array}{l}\text { Tidak } \\
\text { Percaya } \\
\text { terhadap } \\
\text { imunisasi }\end{array}$ & 8 & 21,1 & 30 & 78,9 & 38 & 100 & 0,000 \\
\hline
\end{tabular}

Hasil penelitian menunjukan ada hubungan antara kepercayaan ibu dengan pencapaian imunisasi dasar lengkap ( $\mathrm{p}=$ 0,000).

Penelitian ini sesuai dengan Ikawati (2011) yang menyatakan bahwa terdapat banyak faktor yang dapat memberikan pengaruh. Salah satu pengaruhnya yaitu kepercayaan yang dianut atau dipercaya oleh orang tua. Pengalaman buruk dari ibu akan menjadi sumber kepercayaan ibu sehingga dapat mempengaruhi ibu untuk tidak mengimunisasikan anaknya. Namun pada penelitian Ikawati tidak disebutkan distribusi tingkat kepercayaan ibu terhadap imunisasi. Berdasarkan hasil ini menandakan bahhwa terdapat persamaan kepercayaan responden mengenai imunisasi. Hal ini menandakan bahwa ibu yang berada di Kabupaten Sampang tidak jauh beda dengan ibu yang berada di Kabupaten Sumenep. Penelitian ini betentangan dengan Rahmawati (2013) yang menyatakan bahwa tidak ada pengaruh antara kepercayaan terhadap ketidaklengkapan status imunisasi pada bayi atau balita. Penelitian Rahmawati ini memberikan gambaran bahwa kepercayaan antara ibu yang bertempat tinggal di Kota Surabaya berbeda dengan ibu yang bertempat tinggal di Kecamatan Gayam Kapubaten Sumenep. Hal ini memberikan informasi bahwa kepercayaan dipengaruhi oleh kultur daerah dimana responden tinggal.

Adanya pengaruh dalam hasil penelitian ini disebabkan oleh sebagian besar responden percaya bahwa imunisasi memberikan dampak baik terhadap bayi mereka. Hampir tiga perempat ibu mempercayai bahawa imunisasi memberikan dampak baik. Alasan terbanyak ibu mengimunisasikan anaknya yaitu membuat bayi sehat $(90,6 \%)$ dan terhindar dari penyakit $(56,6 \%)$.

Sumber informasi yang didapatkan oleh 106 responden yang percaya terhadap program imunisasi yaitu tertera pada tabel 4 sebagai berikut

Tabel 4. Sumber informasi responden percaya terhadap program imunisasi

\begin{tabular}{lcc}
\hline Sumber informasi & Frekuensi & $\%$ \\
\hline $\begin{array}{l}\text { Diri sendiri / } \\
\text { pengalaman pribadi }\end{array}$ & 77 & 53,5 \\
\hline $\begin{array}{l}\text { Orang lain (Orang } \\
\text { tua, bidan dan kader) }\end{array}$ & 29 & 20,1 \\
\hline Total & 106 & 73,6 \\
\hline
\end{tabular}

Hasil ini didapatkan bahwa kepercayaan ibu terhadap imunisasi didapatkan dari diri sendiri/pengalaman pribadi serta didapatkan dari dorongan dan dukungan dari bidan desa dan para kader serta keluarga. Hasil ini menandakan adanya bentuk dukungan informatif dari orang lain terhadap ibu. Hal ini menandakan bahwa kepercayaan terhadap imunisasi tersebut memungkinkan ibu memiliki sikap yang baik sehingga menghasilkan tindakan yang positif dalam perilaku kesehatan.

\section{4) Hubungan Sikap Ibu dengan Pencapaian Imunisasi Dasar Lengkap}

Berdasarkan hasil penelitian, ibu dengan sikap baik mendapatkan proporsi status imunisasi lengkap lebih banyak daripada proporsi dengan status imunisasi tidak lengkap. Hal ini memungkinkan ibu 
untuk berperilaku selalu mengimunisasikan anaknya. Hasil berbeda terdapat pada ibu yang memiliki sikap kurang baik. Ibu yang memiliki sikap kurang baik cenderung tidak mengimunisasikan anaknya. Sehingga proporsi ibu melakukan imunisasi lengkap lebih sedikit daripada imunisasi lengkap.

Tabel 5. Hubungan sikap ibu dengan pencapaian imunisasi dasar lengkap pada bayi di wilayah kerja Puskesmas Gayam

\begin{tabular}{|c|c|c|c|c|c|c|c|}
\hline \multirow{3}{*}{$\begin{array}{c}\text { Sikap } \\
\text { Ibu }\end{array}$} & \multicolumn{4}{|c|}{ Status Imunisasi } & & & \multirow{3}{*}{$\underset{\text { value }}{p}$} \\
\hline & \multicolumn{2}{|c|}{ Lengkap } & \multicolumn{2}{|c|}{$\begin{array}{c}\text { Tidak } \\
\text { Lengkap }\end{array}$} & \multicolumn{2}{|c|}{ Total } & \\
\hline & $\mathrm{n}$ & $\%$ & $\mathrm{n}$ & $\%$ & $\mathrm{~N}$ & $\%$ & \\
\hline Baik & 57 & 73,1 & 21 & 26,9 & 78 & 100 & \\
\hline $\begin{array}{l}\text { Kurang } \\
\text { Baik }\end{array}$ & 20 & 30,3 & 46 & 69,7 & 66 & 100 & 0,000 \\
\hline
\end{tabular}

Hasil penelitian menunjukan ada hubungan antara sikap ibu dengan pencapaian imunisasi dasar lengkap $(\mathrm{p}=$ 0,000).

Penelitian ini memiliki kesamaan dengan Oktaviani (2015) yang menyatakan bahwa sikap ibu berpengaruh terhadap penolakan ibu dalam pemberian imunisasi dasar lengkap. Selain itu sikap ibu juga berhubungan dengan penolakan pemberian imunisasi dasar lengkap. Penelitian ini juga didukung oleh Dwiastuti dan Prayitno (2013) bahwa sikap ibu memiliki hubungan yang bermakna dengan pemberian imunisasi.

Teori Alport menyebutkan bahwa sikap memiliki 3 komponen pokok yaitu kepercayaan atau keyakinan, ide, dan konsep terhadap objek, kehidupan emosional atau evaluasi seseorang terhadap objek, dan kecenderungan untuk bertindak. Komponen tersebut akan membentuk sikap yang utuh dari seseorang (Notoatmodjo, 2010). Jadi faktor sikap tidak dapat berdiri sendiri, ada faktor lain yang mendukung dalam terjadinya sikap yaitu faktor kepercayaan. Berdasarkan hasil sumber informasi kepercayaan responden pada tabel 4, kepercayaan ibu diperoleh dari pengalaman pribadi dan dorongan orang lain. Menurut Notoatmodjo (2010) Sikap sering diperoleh dari pengalaman sendiri atau dari orang lain yang paling dekat. Hal ini menandakan bahwa sikap dibangun oleh kepercayaan seseorang.

Selain itu, faktor pengetahuan juga memungkinkan untuk membangun sikap seseorang. Apabila seseorang berpengetahuan baik kemungkinan akan menunjukan sikap yang baik pula begitu pula sebaliknya. Namun pada penelitian ini didapatkan bahwa mayoritas ibu memiliki sikap baik walaupun pada faktor tingkat pengetahuan didapatkan proporsi bahwa pengetahuan ibu tergolong tingkat pengetahuan rendah. Pengetahuan yang rendah didapatkan karena mayoritas responden memiliki tingkat pendindikan yang rendah pula. Meskipun mayoritas responden memiliki pengetahuan yang rendah, akan tetapi responden mendapat dukungan sosial (social support) dari keluarga, bidan dan kader sehingga memungkinkan untuk ibu mengimunisasikan anaknya secara lengkap. Dukungan sosial inilah yang memungkinkan ibu bersikap baik terhadap imunisasi, sehingga menghasilkan tindakan yang positif dalam perilaku kesehatan.

Selain itu, sikap dapat di pengaruhi oleh faktor pengalaman pribadi, pengaruh orang lain yang dianggap penting, pengaruh kebudayaan, media massa, lembaga pendidikan dan lembaga agama, dan faktor emosional (Azwar, 2013). Salah satu faktor yang mempengaruhi sikap adalah pengaruh orang lain yang dianggap penting. Pada penelitian ini dibutuhkan peran kader, bidan desa dan pemegang program imunisasi untuk memberikan informasi dan pemahaman sehingga berpengaruh terhadap sikap ibu. Apabila kader kesehatan, bidan desa dan pemegang program dapat menjalankan perannya sebagai ujung tombak upaya preventif (pelayanan imunisasi) maka seluruh ibu dapat bersikap baik dalam melakukan imunisasi pada anaknya.

\section{SIMPULAN}

Berdasarkan analisis hasil dan pembahasan diatas, maka diperoleh kesimpulan bahwa sebagian besar ibu yang mempunyai bayi di wilayah kerja Puskesmas Gayam berumur $\leq 30$ tahun, tingkat pendidikan rendah (< SMA), berstatus tidak bekerja, tingkat 
pengetahuan kurang, percaya terhadap imunisasi, dan memiliki sikap baik terhadap imunisasi.

Tingkat pendidikan ibu dan tingkat pengetahuan ibu menjadi faktor yang perlu ditingkatkan dalam pencapaian imunisasi dasar lengkap diwilayah kerja Puskesmas Gayam Kabupaten Sumenep. Dibutuhkan peran petugas kesehatan, pemegang program imunisasi dan kader untuk memberikan pemahaman khusus baik melalui pesan media maupun peragaan. Pemberian media informasi memberikan tambahan pengetahuan dari ibu di Puskesmas Gayam. Media informasi yang mendukung seperti leaflet yang berisi gambar dan penjelesannya dengan menggunakan bahasa sederhana atau bahasa daerah.

Pengetahuan dan kepercayaan akan memberikan sikap pada seseorang. Peran petugas kesehatan dalam memberikan penambahan pengetahuan terhadap ibu serta dorongan untuk melakukan imunisasi membuat ibu bersikap baik dalam melaksanakan program imunisasi. Apabila pengetahuan, kepercayaan dan sikap ibu telah baik maka akan meningkatkan pencapaian imunisasi dasar lengkap di wilayah kerja Puskesmas Gayam Kabupeten Sumenep.

\section{DAFTAR PUSTAKA}

Azwar, Saifuddin. 2013. Sikap Manusia Teori dan Pengukurannya. Yogyakarta: Pustaka Pelajar Offset

Balitbang Kemenkes RI. 2013. Riset Kesehatan Dasar; RISKESDAS. Jakarta: Balitbang Kemenkes RI

Depkes RI, 2000, Pedoman Operasional Pelayanan Imunisasi, Jakarta: Depkes RI

Depkes RI. 2005. Profil Kesehatan Indonesia 2005. Jakarta: Departemen Kesehatan RI.

Depkes RI. 2007. Profil Kesehatan Indonesia 2007. Jakarta : Departemen Kesehatan RI

Delan, A., 2011. Hubungan Antara Tingkat Pengetahuan Ibu, Tingkat Sosial Ekonomi dengan Status Imunisasi Dasar Lengkap Pada Balita. Skripsi. Universitas Dipenogoro Semarang

Dewi, A., Darwin, Edison., 2013 Hubungan Tingkat Pengetahuan Ibu dengan Pemberian Imunisasi Dasar Lengkap Pada Bayi di Kelurahan Parupuk Tabing Wilayah Kerja Puskesmas Lubuk Buaya Kota Padang Tahun 2013. Jurnal Kesehatan Andalas. 2014;3(2) : 1-5

Dwiastuti, P., Prayitno, 2013. FaktorFaktor yang Berhubungan dengan Pemberian Imunisasi BCGdi Wilayah Puskesmas UPT Ciamis Kota Depok Tahun 2012. Jurnal Ilmiah Kesehatan, Vol 5 No.1: 36-41

Idwar, 2000. Faktor-faktor yang Berhubungan dengan Status Imunisasi Hepatitis B pada bayi (0-11 bulan) di Kabupaten Aceh Besar, Provinsi Daerah Istimewa Aceh Tahun 1998/1999. (diakses pada http://digilib.litbang.depkes.go.id Tanggal 14 November 2016)

Ikawati, N. A., 2011. Pengaruh Karakteristik Orang Tua Terhadap Status Kelengkapan Imunisasi Dasar Pada Bayi di Kelurahan Banyuanyar Kabupaten Sampang. Skripsi. Fakultas Kesehatan Masyarakat Universitas Airlangga Surabaya

Kementerian Kesehatan RI, 2013. Peraturan Menteri Kesehatan No. 42 Tahun 2013 tentang Imunisasi. Jakarta; Kementerian Kesehatan RI 2013

Kemenkes RI, 2014. Data dan Informasi Tahun 2013 (Profil Kesehatan Indonesia). Jakarta : Kemenkes RI 2014.

Kemenkes RI, 2015. Profil Kesehatan Indonesia Tahun 2014. Jakarta : Kementrian Kesehatan RI 2015

Kemenkes RI, 2016. Profil Kesehatan Indonesia Tahun 2015. Jakarta : Kementrian Kesehatan RI 2016

Mubarak, W. H. (2006). Pengantar Keperawatan Komunitas 2. Jakarta: Sagung Seto 
Ningrum, 2008. Faktor-faktor yang Mempengaruhi Kelengkapan Imunisasi Dasar pada Bayi di Puskesmas Banyudono Kabupaten Boyolali. (diakses pada https://publikasiilmiah.ums.ac.id/bitstream/ handle/11617/460/1b.pdf?sequence $=1 \&$ isA llowed=y Tanggal 4 April 2017)

Noor, N. N., 2000. Dasar Epidemiologi. Jakarta: Rineka Cipta

Notoatmodjo, S., 2003. Pendidikan dan Perilaku Kesehatan. Jakarta : Rineka Cipta

Notoatmodjo, S., 2010. Promosi Kesehatan Teori dan Aplikasi. Jakarta : Rineka Cipta.

Notoatmodjo, S., 2014. Ilmu Perilaku Kesehatan. Jakarta : Rineka Cipta.

Oktaviani, Faradilla Alif, 2015. Faktor Yang Mempengaruhi Penolakan Ibu Terhadap Pemberian Imunisasi Dasar Lengkap Di Wilayah Puskesmas Kamoning Kabupaten Sampang Tahun 2014. Skripsi. Universitas Airlangga Surabaya

Peraturan Menteri Kesehatan Republik Indonesia Nomor 42 Tahun 2013 Tentang Penyelenggaraan Imunisasi

Prayogo, A., dkk., 2009. Kelengkapan Imunisasi Dasar pada Anak Usia 1-5 Tahun. Jurnal Sari Pediatri, Vol. 11 No. 1: 1-6.

Puskesmas Gayam, 2016. Profil UPT. Puskesmas Gayam Kecamatan Gayam Kabupaten Sumenep tahun 2015. Sumenep; Puskesmas Gayam

Rahmawati, A. I. 2013. Faktor yang Mempengaruhi Kelengkapan Imunisasi Dasar di Kelurahan Krembangan Utara Kota Surabaya Sebagai Upaya Pencegahan Penyakit PD3I. Skripsi. Fakultas Kesehatan Masyarakat Universitas Airlangga Surabaya

Rini, A. P. 2009. Hubungan Antara Karakteristik, Jumlah Anak, dan Pengetahuan Ibu terhadap Status Kelengkapan Imunisasi Dasar Pada Bayi di Kelurahan Wonokusumo Kecamatan Semampir Surabaya Tahun 2008. Skripsi.
Fakultas Kesehatan Masyarakat Universitas Airlangga Surabaya

Risnawati, D., 2014. Pengaruh Pengetahuan, Pendidikan, Pendapatan, dan Budaya Ibu Terhadap Kelengkapan Imunisasi Dasar Lengkap di Kelurahan Pacarkembang. Skripsi. Fakultas Kedokteran Universitas Airlangga Surabaya

Rizqiawan, A., 2008. Faktor yang Mempengaruhi Ibu dalam Ketidakikutsertaan Balitanya ke Pekan Imunisasi Nasional (PIN) Polio di Wilayah Kerja Puskesmas Mulyorejo Surabaya. Skripsi. Universitas Airlangga Surabaya

Smet, 1994. Psikologi Kesehatan. Jakarta : PT. Gramedia Widiasarana Indonesia

Utami, Tri Mariyana., 2008. Hubungan Faktor Ibu dan Faktor Pelayanan Kesehatan dengan Status Imunisasi Hb Combo 3 Pada Bayi di Dukuh Sutorejo Surabaya. Skripsi. Universitas Airlangga Surabaya

WHO, 2014. Immunization. WHO. tersedia di :

http://www.who.int/topics/immunization/e n/. [14 November 2016].

WHO, 2014. Levels and Trends In Child Mortality 2014. WHO. Tersedia di : www.who.int/entity/maternal_child_adoles cent/documents/levels_trends_child_mortal ity_2014/en/. [ 3 Januari 2017] 